\title{
Why Handling Power Responsibly Matters: The Active Interpreter Through the Sociological Lens
}

\author{
Julia Dahlvik
}

\section{Introduction}

Current developments throughout the world and in specific regions have made asylum one of the key topics of today. Although Europe only hosts a small percentage of the millions of people who had to flee from their homes, ${ }^{1}$ asylum seekers and reception conditions have been in the focus of European mass media and societal debates. As this book perfectly illustrates, social researchers too have started to explore many different aspects of this complex phenomenon. The administration of asylum claims is one of these crucial topics that has become a separate field of investigation. Embedded in the context of the legal procedure, this contribution sets out to highlight the fundamental role interpreters play in enabling communication between asylum claimants and representatives of the state. Most asylum hearings, often the key moment in an asylum procedure, could not take place without the work of an interpreter.

\footnotetext{
${ }^{1}$ No European country was among the top ten receiving countries; the list was led by Turkey with around two and a half million refugees, Pakistan with around one and a half million and Lebanon with over one million.
}

J. Dahlvik ( $ه)$

University of Applied Sciences FH Campus Wien, Vienna, Austria e-mail: julia.dahlvik@fh-campuswien.ac.at 
I adopt a sociological perspective to first explore the relationship between public official and interpreter in asylum interviews. The basic assumption, based on existing literature, is that the relation is more complex than a simple contractee-contractor relation and, as a part of that, interpreters are often in a more powerful position than officials would want them to be. Meanwhile, it seems to be common understanding in the literature that interpreters are active agents rather than passive transmitters of utterances from one language into another (Rycroft 2005; Angelelli 2014). This ethnography hints at the complexity and contours of the power imbalance in asylum interviews. As a consequence, I argue that both researchers and practitioners need to focus more on professionalism and ethics in community interpreting, especially in the context of international protection. While it is no doubt vital to not only talk about interpreters, but also hear their opinion (as well as that of claimants), in this contribution I will focus on the perspective of decision-making officials. ${ }^{2}$

Since the turn of the century at the latest, there has been increasing sociological interest in translation and interpreting. The development of a sociology of translation, often a conceptual and theoretical endeavour, is based on works such as those of Pierre Bourdieu, Bruno Latour, Bernard Lahire, Anthony Giddens (Tipton 2008 in the context of asylum) and Niklas Luhmann, as the anthology edited by the Austria-based researchers Wolf and Fukari (2007) shows. One of the issues, which has nevertheless received too little attention to this date concerns professionalism and professional ethics. Among the few works are those by Wadensjö $(1999,2007)$ and Grbić (2010), who address the topic of professionalism in interpreting, or by Rudvin (2007), who focuses particularly on professionalism and ethics in community interpreting. Both the sociological perspective and the issues of professionalism and professional ethics are at least briefly mentioned in two recent introductory publications in the field of translation and interpreting studies (TIS) (Pöchhacker 2016; Munday 2016). This chapter aims to contribute to this area of research by exploring the relevance of professionalism and professional ethics in the context of asylum administration.

Since the asylum procedure takes place in a legal context, the perspective of legal interpreting and its particular challenges also provides valuable insights. Key works (Morris 1995; Colin and Morris 1996; Berk-Seligson

${ }^{2}$ Due to the institutional perspective of this study, interviews with non-institutional actors were not included. Quotes from interviews with interpreters originate from earlier research (Dahlvik 2009a, b). 
2002) have identified a number of issues relevant to interpreting in this specific field, such as the controversial neutrality of the interpreter, which is connected to an inherent role ambiguity, or questions of power. In relation to professionalism and ethics, power in the interaction represents a key issue in this contribution, which connects to research on interpreter-provider collaboration and conflicts of control in the interpreter-mediated interaction (Hsieh 2010 in the medical context).

Interpreting in the field of asylum has increasingly become an object of research (Inghilleri 2007; Maryns 2013; Lee 2014), including a focus on the role of interpreters in this specific context (Barsky 1996; Rycroft 2005; Gibb and Good 2014; Good 2007). In the Austrian context, a number of studies have been carried out, investigating, for example, conflicting role expectations (Pöllabauer 2007), the interpreter's key role in co-producing the interview transcript (Pöchhacker and Kolb 2009), or mutual understanding and intercultural misunderstanding (Rienzner 2011). While such research is often undertaken from the perspectives of TIS, communication or linguistic studies, researchers are increasingly taking into account sociological aspects. Nevertheless, I argue that more in-depth empirical sociological research is necessary to investigate the interpreter-mediated asylum interview, a complex communication situation characterised by an important power imbalance, and its connection to interpreters' professionalism and ethics.

This chapter adds to existing research by providing new insights from an institutional perspective. First, it explores public officials' perception of interpreters and cooperation with them. Second, this contribution sheds new empirical light on interpreters' active role and room for manoeuvre in doing interpreting in the asylum hearing as well as its conditions and consequences. Building on this, the implications of the analysis for the practice of interpreting in asylum hearings with regard to professionalism are discussed.

The findings discussed in this contribution are based on an institutional ethnography (Smith 2006) case study of a branch of the former Austrian Federal Asylum Office ${ }^{3}$ (FAO). Through a short-term internship at this institution I was able to investigate processes that are otherwise not accessible to the public. The larger study, which focused more generally on the social practices and processes at the FAO, was based on the 'crystallisation' (Richardson 2000) of semi-structured interviews with decision-making officials, participant observation of asylum hearings and office life, as well as analysis of records and other internal documents. For this study, I observed

${ }^{3}$ Since the 1 January 2014, 'Federal Office for Immigration and Asylum'. 
six asylum hearings, which usually lasted several hours; all but one of them took place with an interpreter. In addition to conversations during field research, I carried out 14 semi-structured in-depth interviews with different actors, among them decision-makers at different levels of the Asylum Office (frontline workers as well as supervisors), staff of one of the Initial Reception Centres as well as a judge of the (former) Asylum Court. The analysed artefacts include internal documents, such as work instructions or training programmes, as well as three individual records of former asylum claimants. Data was generated mainly between 2010 and 2012. The analysis of observations, interviews and internal documents first focused on thematic coding (Strauss and Corbin 1990) and subsequently followed the approach of interpretive social research as outlined by Froschauer and Lueger (2009).

In the following, I provide a brief overview of the Austrian asylum system and illustrate how interpreters are typically involved in the procedure. In the second section I explore officials' perspectives on working together with interpreters, including the process of commissioning interpreters, quality considerations regarding the rendered services and officials' use of interpreters' 'expert' knowledge. This is followed by an analysis of interpreters' active interventions in the interaction which discusses them from the perspective of professionalism in interpreting. These interventions include managing the communication situation, taking over control of the situation, and undermining the official's authority as the leader of the hearing. I conclude by highlighting the importance of professionalism and professional ethics in dealing with power relations in such situations of what I call 'proxy communication', especially in the delicate context of international protection.

\section{The Asylum Procedure in Austria and the Interpreter-Mediated Interview}

An asylum application can be lodged with the police. The asylum claimant is then registered and brought to one of the Federal Care Facilities throughout Austria where she lives (at least) for the duration of the admission procedure. In the admission procedure, the Federal Office for Immigration and Asylum (FOIA) assesses whether Austria or another EU member state is responsible for the procedure. If Austria is not responsible, the country through which the claimant entered the EU first is responsible for the procedure (according to the Dublin Regulation). A claimant can lodge a complaint against the decision with the Federal Administrative Court, which will either confirm 
the decision of the FOIA or judge that Austria is responsible. If no complaint is lodged or the Court does not decide differently within seven days, the claimant is transferred to the responsible EU country and can be taken into pre-deportation detention before that. If Austria is responsible, the asylum claimant is assigned an accommodation in a regional facility in Austria. The Länder are then responsible for the basic care. After admission, the FOIA assesses in the substantive procedure whether the asylum claimant is entitled to international protection. If the person is granted asylum and is thereby a recognised refugee, she can stay in Austria and has almost the same rights as an Austrian. However, if there are no flight reasons according to the Geneva Refugee Convention (GRC), but the claimant will be in danger in her country of origin, she receives subsidiary protection. If neither flight reasons nor danger in the country of origin exist, the person may still be able to remain in Austria. Reasons can be that the person has been in Austria for many years already, is well integrated or has family members in Austria. The asylum claim is rejected if no flight reasons according to the GRC are found and the claimant does not have to fear a severe violation of human rights in the country of origin. The claimant can lodge a complaint with the Federal Administrative Court, and subsequently a complaint against the Court's decision with the Constitutional or Higher Administrative Court. If no complaint is lodged with the Federal Administrative Court or the negative decision is confirmed, the claimant has to leave Austria. If she does not do that voluntarily she can be deported to her country of origin. A complaint or revision with the Constitutional or Higher Administrative Court is possible but these options are non-suspensive, meaning that a deportation will not necessarily be postponed until they have been concluded.

Interpreters can be involved at any stage of the procedure where face-toface communication between asylum claimant and representatives of the authority is necessary, for example in the admission procedure, during legal counselling, or, if another interview is deemed necessary, in the complaints procedure at the Federal Administrative Court. This contribution focuses on the interview in the substantive procedure, which represents a cornerstone of the procedure. These interviews take place in caseworkers' offices, where claimant, official and interpreter are supposed to sit in a triangle. The official leads the interview and types the transcript at the same time. At the end of the interview, which follows a specific structure, the interpreter sight-translates the transcript back into the original language so that the asylum claimant has the possibility to make corrections before verifying the completeness and correctness of the transcript with her signature. The transcript is the key outcome of the interview and serves as a basis for future decisions. One of the interpreters 
explains why she likes to sit in a place where she sees the computer screen (a seating constellation which tends to ignore the prescribed triangle), 'Eventually, I'm liable for the transcript and the back translation. For many years I've been watching what the official is typing; it has become a habit.'

There are procedural rules on the involvement of interpreters as well as norms on the nature, extent and manner of interpretation, the exclusion (due to partiality) and liability of interpreters (Kadrić 2009) However, the concrete form of the interpreter's role and a delimitation of her duties are not legally defined (Maurer-Kober 2006). The Act on expert witnesses and court interpreters regulates the administration of oath and registration of court interpreters, but not their implementing power. At court, it is legally the judge's and not the interpreter's decision, what is interpreted and what is not. According to Kadrić (2009), however, interpreters are usually not prevented from acting independently. In addition, interpreters are often understood as experts and assistants and thus as advisors of the court (ibid.). The study findings suggest a similar situation at the authority. It is, however, important to note that in the administrative asylum procedure court-certification of interpreters is recommended but not legally required (Pöllabauer 2005). In addition, there are several languages for which no certified interpreters are available. Although it is possible to swear-in interpreters 'ad hoc' at court, Berk-Seligson (2002) points out that not even an oath sworn before court can guarantee sufficient qualification. Concerning the role of the interpreter in the Austrian asylum procedure, UNHCR Austria (2015) has recently edited a training handbook for interpreters in this context.

\section{Discussion of Findings ${ }^{4}$}

\section{Officials' Perspectives on Working Together with Interpreters}

This section explores how caseworkers perceive and relate to interpreters, who are not members of the government institution but externally commissioned. Decision-makers do not only have legal discretion; they also have room for manoeuvre in a broader sense, for example, regarding the choice of the interpreter. While officially they should commission different interpreters, as an official explains, the reasons for this rule are not quite clear; it might be regarded as a measure against coalition-building. According to

\footnotetext{
${ }^{4}$ Parts of this chapter are based on an earlier publication (Dahlvik 2018).
} 
the official, however, the rule is rarely implemented since 'that's just difficult $[\ldots]$ because if you work well together with one [interpreter], are satisfied with him, he knows how you work, I have the feeling he's neutral, why should I then appoint another one?'. Considering her good and bad experiences with different interpreters, it makes more sense for her to re-appoint an interpreter with whom she already works well together. Commissioning interpreters is one of the areas where officials' individual approaches and strategies in dealing with asylum claims are visible.

A key issue regarding the cooperation between caseworkers and interpreters that emerged from the data is the quality of interpreters' work, which relates to issues of professionalism. Since court-approved interpreters exist only for a limited number of languages, for other languages uncertified interpreters need to be commissioned who may still have a university degree or other interpreting training. In addition, officials point out that whilst for some languages there is a larger pool of interpreters to choose from, for less common languages it is often difficult to find an 'appropriate' interpreter. To facilitate the commissioning process, there is thus an internal list of uncertified interpreters in addition to the official, publicly available list of certified interpreters. Again, this illustrates the coexistence and complementarity of formal and informal norms in the institution and is an example of legal pluralism (see Gill and Good, this volume).

\section{Quality of Work as an Aspect of Professionalism}

Some officials point out that the lack of competences of untrained interpreters can lead to specific problems in the interpreting situation affecting the other participants. A caseworker explains that some interpreters are not more than 'stopgap solutions which you don't [commission] anymore'. She adds, however, that sometimes there are no viable alternatives to commissioning problematic interpreters, 'for some countries [that is, languages] there are no good interpreters, but you still have to recourse to them time and again'. ${ }^{5}$ Untrained interpreters are stopgap solutions esecially if they do not speak German properly. Officials are aware of this highly problematic situation, 'because you don't know, does he translate it correctly? Or when writing the transcript: you have to turn the sentence around three times and then you can be sure that it's not as the asylum claimant said it', a

\footnotetext{
${ }^{5}$ The quote also highlights the problem that countries of origin tend to be equated with one specific language, indicating a certain (deliberate) ignorance of the complexity of reality such as language varieties (Angermeyer 2013; Maryns 2017).
} 
caseworker explains. This translation of 'her [the interpreter's] German into my German', as another official puts it, can obviously have profound consequences. The official, Gabi, remembers a 'catastrophic' interview 'with a desperate asylum claimant, all in tears, and an interpreter in quotation marks who doesn't speak German, who can't express herself'. It is needless to say that commissioning unqualified interpreters in these crucial communication situations, decisive for the granting of international protection, can have dreadful consequences. The communication between two parties who do not understand each other is necessarily bound to fail when the interpreter does not possess the required language and interpreting skills.

The cooperation between official and interpreter is also connected to the relation between interpreter and asylum claimant. Officials often mention that some interpreters may be biased which is regarded as problematic since it deviates from the idea of the neutral interpreter. ${ }^{6}$ A potential bias, however, only seems to be a problem when it is oriented towards the claimant. In contrast, caseworkers typically tolerate or even appreciated it when interpreters act as their assistants in the intevriew. In particular when 'former asylum claimants', as recognised refugees, are commissioned for interpreting - which is sometimes the case if no certified interpreters are available for a certain language- 'you don't know on which side they are', a caseworker highlights. Officials point out that interpreters sometimes also take sides against the claimant, which is often related to ethnic group conflicts (see also Scheffer 2001). In other cases, however, when asylum claimants and interpreters share experience, for instance, from the same country of origin, officials argue that claimants hope to get support from interpreters; this, they say, is reinforced when the latter have also gone through the procedure as claimants before. Interpreters are thus potentially also in the position to do advocacy. As Inghilleri (2003: 259) points out, 'the decision to serve as conduit or advocate may result from interpreters' qualifications, experiences or cultural understandings of the applicants or what is at stake for the applicants in the proceedings'. But even if officials find biased interpreters problematic, there are often no alternative choices.

${ }^{6}$ While the position of intepreters as neutral language transmitters can still be found in some of the literature, this role definition has been challenged for some time now in TIS (Gile 2009). 


\section{The Interpreter as a Resource and Cooperation as a Game of Power}

The idea that interpreters should be neutral seems to conflict with the fact that they sometimes take-or are brought into-the role of being officials' work colleagues. Since the official is the one who commissions the interpreter-the claimant generally does not have a say in this decision (except regarding gender) - it is in her interest to find a person she is able to work with. As mentioned above, the official, Gabi, finds it natural to re-commission an interpreter if they 'work well together'. The official describes her relation to an interpreter in the ideal case as a good team, that is, two persons who are well attuned to each other and know each other's expectations. If an official is satisfied with an interpreter's work she will thus commission her again instead of looking for another person (the same is true for commissioned experts). Continuous good cooperation may, however, provoke the appearance vis-à-vis an asylum claimant that official and interpreter work together in an alliance-and this might not only be an appearance. Consequently, the question of the interpreter's neutrality or bias arises again, since the interpreter might be seen as or even start to act like a member of the institution, especially if she is not professionally trained. This might be the case, for instance, when the interpreter starts questioning the claimant without the official having asked a question.

The observation that officials and interpreters cooperate-to a smaller or larger extent-suggests that interpreters do more than 'just' translate, as previous studies have also shown (Angelelli 2004; Llewellyn-Jones and Lee 2014). While one of the caseworkers first holds that interpreters 'are there to translate and do nothing else', he then admits that this does not correspond to reality by adding that 'for countries [of origin] where [he is] not really sure' he will also consult the interpreter for expertise. The official explains that he sometimes uses the interpreter's knowledge in order to verify the information provided by the claimant (see also Kadrić 2009). Although officials cannot know how up-to-date or valid an interpreter's knowledge is, this kind of information can feed into decisions on asylum claims. The fact that interpreters often also possess expert knowledge additionally makes them a valuable resource and partner for cooperation. In the asylum procedure, in order to decide upon an application, officials mostly depend on information from 'outside' the institution (such as independent expert opinions), and 
interpreters represent one such source. ${ }^{7}$ Many interpreters who grew up or spent a long time in the country in question are hence regarded as knowledgeable concerning the local circumstances. 'Because some things you don't think of as an official because you're not from that cultural area [...]; sometimes there have been really good ideas or hints, which I'd never have thought of. I just think in a Western way and how it is here', the official Sabine explains. Due to their specific backgrounds interpreters can sometimes provide officials not only with additional knowledge but also with new perspectives, pointing out differences to life in Europe, as illustrated in the passage from an observed interview.

Official: Street names? House numbers? Do they exist there? Interpreter: They don't exist.

Although officials depend on the interpreter for communicating with the asylum claimant, they are eager to manipulate the power balance to their benefit by trying to keep control of the situation. Officials can decide whether to ask an interpreter for advice but they also have the power to decide how to proceed with the information provided. Even if the official has recourse to the interpreter's knowledge, Veronika highlights that 'the decision is eventually mine'. On the other hand, the interpreter has the power to decide which information to give the official and which to withhold. An official remembers an interview situation where the claimants' children started to cry and the interpreter told him afterwards that the mother had told the children to cry. Hence, in some aspects the interpreter is always one step ahead, which puts her in a powerful position in relation to the official. This will become even more obvious in the following analysis of situations in interpreted asylum hearings.

\section{Active Interventions in the Interaction}

In line with existing research, the findings show that interpreters do not 'only' translate what other interaction participants say but often act in a proactive way. According to Wadensjö (1999), the interpreter's active participation is 'part and parcel of all interpreting'. The author thus also regards coordination as one of the interpreter's tasks, this includes both 'implicitly

\footnotetext{
${ }^{7}$ An official explained that some interpreters are even commissioned as experts to produce reports on specific topics.
} 
co-ordinating or gatekeeping contributions' and 'explicitly co-ordinating contributions' (ibid.). Similarly, Turner and Brown (2001) argue that managing and negotiating the communication situation is one of the interpreter's responsibilities. In her analysis of court interpreters' behaviour, Berk-Seligson (2002) identifies different kinds of active intervention such as interrupting, explaining, silencing and 'controlling the flow of testimony'. Similar actions could also be observed in the present study; in this section they are analysed in the light of professional behaviour.

The statement of one of the trained interpreters highlights their room for manoeuvre regarding active interventions in the interaction as well as the unequal power balance among the actors:

If something seems contradictory to me [...] then I ask [the claimant] what he means. Although that's also bad; actually the official should do that. When I think, 'that's impossible,' for instance, when [the claimant] mentions three different birth dates, then I make a comment to the official. Otherwise he might think that my translation is wrong [...]. Sometimes, I have to ask a spontaneous question of understanding [to the claimant]; then I explain that [to the official ...]. Often when there are longer passages ... it can be difficult to bring the translation to an end because the official says, 'we know that already' [...] Then I have little chance to complete the interpretation. But I rarely tell the asylum seeker that I haven't interpreted everything. That's a bad situation.

The quote illustrates different ways the interpreter can manage the communication situation, and that, in this case, they tend to be to the disadvantage of the asylum claimant. The interpreter feels that she has to justify her-seemingly inappropriate-behaviour in front of the official, but not vis-à-vis the claimant. At the same time, she knows and acknowledges that her action does not correspond with professional ethics, mentioning twice that the situation is 'bad.' She seems to find herself in a dilemma since she knows what would officially be the right thing to do but feels the urge to act differently. Professionalism and professional ethics immediately come into play and it seems difficult for the interpreter to make them compatible with the pressures of a real-life interpreting situation.

In a similar vein, the following scenes from observed asylum hearings show how the interpreter actively structures the interaction and thusat least for a moment-takes control of the situation. In these situations, often a conversation between interpreter and official takes place while the claimant is left out of the conversation or talked about in the third person. I will discuss three key aspects: first, situations in which the interpreter's aim 
is to manage and clarify the communication situation; second, situations in which the interpreter tries to take over control of the communication situation; and third, situations in which it is questionable whether the interpreter takes her job seriously. While the first section includes situations where the interpreter demonstrates professional behaviour, the other two sections highlight problematic situations, where the interpreter acts in an unprofessional way. The analysis suggests that the interpreter's problem awareness and reflexivity about her own role and action-that is professional ethics-represent key issues that need to be tackled.

\section{Professional Attitudes: Managing the Communication Situation}

In some situations, the interpreter feels that she needs to clarify the communication situation because something is unclear, misunderstood or simply wrong. In one situation, for instance, the interpreter feels the urge to untangle the communication and prevent any misunderstanding. In the following example from an observed hearing, the interpreter is unable to follow the asylum claimant and keeps asking the claimant for clarification. This is what happens next:

Interpreter to claimant: I don't know the story, so tell me the way that I understand it.

Interpreter to official: I can only translate something when I understand him; otherwise you'll be confused too.

Official: Please just translate anyway.

Interpreter: Okay, I'll tell you what he says, but it won't make any sense.

(interview 3)

Since the interpreter does not understand what the claimant is trying to say he asks him to explain it in a way that he will be able to understand what he means. In the same moment, the interpreter explains to the official why he just made an intervention and what the content of this intervention was in order to justify his unexpected behaviour. Aiming at preventing a misunderstanding, the interpreter takes the initiative to ask the claimant for clarification. The official, however, does not approve of this intervention and asks him to translate what the asylum claimant says without any further clarifications. He obviously does not want to lose control of the situation and wants to be able to judge the claimant's assertion himself without being patronised by the interpreter. The interpreter accepts the official's attempt to re-establish 
the formal power relation but warns him that the translation will not make much sense. In order to save his face, he thereby makes sure that the official knows that it is not his translation which is confusing but the claimant's assertion. The fact that he warns the official that misunderstandings might arise can also be interpreted as a measure to ensure his professionalism.

The following passage illustrates a situation in which the interpreter reacts to an odd, unexpected situation. While the interpreter is retranslating the interview transcript the claimant normally has the possibility to announce mistakes in the transcript, for example, when she said something different in the interview than what now appears in the transcript. In the current context, however, the claimant seems to fall asleep while the interpreter is back-translating the transcript:

Interpreter to official: She [the claimant] is sleeping. Do you want me to continue to read?

The official does not react to his question.

Interpreter to claimant. Do you hear?

Claimant: Yes.

(interview 2)

Since the claimant's eyes are closed, the interpreter regards her service as unnecessary and asks the official whether she wants her to continue with the retranslation although the claimant seems not to be listening. But the official does not react; presumably because she does not listen and does not expect to be addressed in this moment. Since the official does not seem to care whether the claimant pays attention to the translation in order to verify the transcript's correctness, the interpreter takes the initiative and asks the claimant herself whether she is listening. When the claimant affirms that she is listening to the interpreter, the situation is clear and the interpreter continues with the back-translation.

\section{Unprofessional Attitudes: Over-Cooperating with the Official}

While sometimes interpreters need to manage a communication situation in order to establish clarity and prevent misunderstandings, in other observed interview situations the interpreter behaves like an assistant official; this is a well-known phenomenon (Donk 2016[1994]; Scheffer 2001; Pöllabauer 2005). The following scenes are examples of situations in which the interpreter seizes the power of definition concerning the course of the interview: 
The claimant says something.

Interpreter to official: That's completely off-topic. (o.i. 6)

The claimant tells something.

Interpreter to official: She now continues to talk about her sisters. Do you want to...?

Official: How does it relate to the departure?

(interview 7 , same interpreter)

In these two situations the interpreter does not translate what the claimant says but instead makes a comment to the official. Due to his experience regarding asylum hearings the interpreter claims to know what is relevant for the procedure and what is not. Instead of leaving the judgement to the official the interpreter judges himself that what the claimant says is not relevant. The interpreter does not translate the claimant's statement but presents his own conclusion, namely that the statement is off-topic. Only then, after his comment, he leaves it open to the official to decide whether she wants to hear the translation or not. In the second situation, the interpreter provides a summary instead of a translation, again taking over control of the communication. Before directly translating what the claimant says, he asks the official if she wants to know what the claimant is saying. The official, instead of listening to the translation, asks another question. The same is true for the following scene, where the interpreter again provides a summary instead of a translation:

Interpreter to official: He's now talking about the flight reason.

Official: No, I just want to know what's with the house.

$[\ldots]$

Interpreter to official: Now he's repeating himself.

(interview 4)

The interpreter makes a comment to the official, assuming that what the claimant said is not what the official wanted to know. Instead of translating what the claimant said, the interpreter anticipates the official's reaction because he knows what he is expecting. The official confirms the interpreter's premonition by dismissing the translation and repeating the intention of his previous question. Also in the second observed instance the interpreter does 
not translate but provides a summary to the official. The interpreter refuses to translate what the claimant said because he has already translated it before since the claimant is allegedly repeating herself. Another scene focuses on a situation where the interpreter comments on the claimant's assertion and his in/credibility. During the interview the asylum claimant shows a big wound on the arm, explaining that a man bit her:

Official: Why do you think he [the perpetrator] bit you?

Claimant (Interpreter): Because I cried and maybe people heard it.

Interpreter to official: If someone bites me I'll cry even more.

(interview 1)

At this point the interpreter does not only translate the claimant's statement but subsequently adds his own opinion on this statement, instead of leaving the judgement to the official. The interpreter calls the claimant's credibility into question, assuming that what she said is not true. In addition, his judgement originates from a comparison with his own potential behaviour, thus measuring the claimant's assertion by his personal standards. In this case the interpreter does not provide specific expert knowledge to the official as discussed before but a personal opinion. Even if the official decides to ignore the interpreter's comment such interfering behaviour does not convey professionalism and strongly questions his alleged neutrality.

\section{Unprofessional Attitudes: Not Taking the Job and the Asylum Claimant Seriously}

The third aspect to discuss in the context of interpreters' practices relates to their general attitude and behaviour in doing their job, which can be understood as key elements of professionalism. For instance, an interpreter who demands that the claimant be interviewed without her children because she cannot concentrate otherwise (o.i. 7) shows that there are certain preconditions for her to be able to work properly. In contrast, there are interpreters who seem not to take their job seriously by not acting adequately for the context of an asylum interview. In the following scene, for example, the interpreter behaves in a disrespectful way towards the asylum claimant:

The interpreter is leaning backwards with stretched legs. The claimant keeps leaning forward when the interpreter translates what the official says.

During the interview the interpreter's mobile phone rings; he picks it up.

The official excuses the interpreter in front of the claimants. 
Interpreter: It was only concerning my car.

Official: Can we continue?

The interpreter agrees by humming ('mhm').

$[\ldots]$

Official: How far is it to the Indian border?

Interpreter: Not so far.

Official: Ask the asylum claimant please!

$[\ldots]$

Official: Where are you living? Basic care, right, a guesthouse.

Interpreter: He says, he's living completely privately now.

Official: I'll check what's registered in the computer.

The interpreter does not interpret the official's comment.

Official to interpreter: Would you be so kind to tell it to him? (o.i. 5)

On the one hand, the interpreter shows disinterest through his body language, leaning backwards with stretched legs. In order to understand the interpreter, the asylum claimant seemingly has to lean forward as he does so every time the interpreter translates what the official says. On the other hand, the interpreter also behaves impolitely und disrespectfully when he picks up his mobile phone and starts talking during the interview. Without hesitation and without a comment to the asylum claimant or the official he interrupts the interview. Instead, the official, who seems to be embarrassed by the interpreter's behaviour, excuses the interpreter in front of the claimant. The official, however, does not sanction the interpreter's behaviour, for instance, by reprimanding him and reminding him of the official setting. After the interpreter finished his call and explained that it was nothing important, the official asks him whether they can now carry on with the interview. ${ }^{8}$ In the course of the interview, the interpreter continues to disregard the claimant by not translating certain statements. At one point, he seems to believe that the official addresses him with a question, which is actually aimed at the claimant. Since the interpreter answers the question in

\footnotetext{
${ }^{8}$ The official is generally rather reluctant to criticise the interpreter's unprofessional behaviour in this interview, possibly to save the interpreter's face in front of me, the observer. Another explanation for why the interpreter is so powerful here could be that there are few alternative interpreters available for the required language, or other unknown dependencies.
} 
lieu of asking the claimant, the official requests the interpreter to translate his question for the claimant. At a later point, this situation is repeated since the interpreter does not find it necessary to translate the official's comment for the claimant, but the official does, prompting the interpreter to translate his comment. The interpreter obviously did not deem it necessary to inform the asylum claimant of the official's intention. If the official were not so persistent in this communication situation (maybe due to my presence), the claimant would not have a serious chance to participate in this interaction. In sum, this interview is far away from a fair communication situation with equal participants.

\section{Conclusion: Learning to Handle Power Responsibly}

The empirical data discussed in this chapter illustrate that interpreters do more than 'just translate': while in some cases they provide the official with 'expert' knowledge, in other situations they influence or manipulate the communication between asylum claimants and officials. This influence can be in favour of the official or the interpreter themselves; but interpreters sometimes also actively try to help the claimant (Gill et al. 2016). The analysis reveals that instead of being neutral mediators, interpreters influence the interaction and thus the development of the further asylum procedure; if interpreters act unprofessionally, this can be to the detriment of a fair procedure. Professional action can be drawing the officials' attention to important issues, such as real and potential misunderstandings or mistakes in the transcript, or explaining their own behaviour to the official in order to prevent misunderstandings. In contrast, problematic and unprofessional behaviour can be summarising instead of translating, making judgements in lieu of the official or commenting on a claimant's account's credibility. Interpreters' work attitude, which is sometimes expressed through disrespectful, disinterested or lazy behaviour, such as deciding on the relevance of a statement by not translating it or not even listening to claimants' assertions, can have important consequences. In sum, this ethnography highlighted the dynamics of power in a situation of distinct power asymmetry. While interpreters' actions and decisions are influenced by different (social, professional, institutional) norms, they dispose of significant room for manoeuvre in the social interaction of asylum hearings, which calls for responsible agency and handling of power (see also Gibbels and Schmitz 2015). 
Professionalism and professional ethics influence how interpreters perform their role and thus also how they handle power. This in turn affects their relation to officials and asylum claimants. Professionalism and professional ethics promote consciousness and reflexivity of the interpreter's own role. A professional role performance does not imply passive neutrality, it means conscious and reflexive- that is professional-active intervention. Although many authors have already insisted on the impossibility of the interpreter's neutrality (Rycroft 2005), the question continues to be discussed: Do neutrality and professionalism presuppose or complement or exclude each other? Gill et al. (2016) point out that interpreters who do not carry out the role of neutral facilitators of communication may not only confuse appellants as to their capabilities, but also lose their professional credibility in the eyes of other actors'. It is, however, still unclear what this neutrality is. I would argue that the same could happen if they try to provide a 'verbatim' translation-a requirement that seems to be a widespread legal fiction (Good 2011) — or do not take sides when it would be ethically necessary. In my view, a complete translation that contains all details is more important and can be more useful than a verbatim translation, which the official might not understand. Professional ethics should help to make the right decisions in order to reach a complete translation. For example, as mentioned in the first section, is it more professional to stick to the rule of sitting in a triangle or to make sure that the official produces a correct transcript? Ideally, a situation should be created where both are possible.

With this contribution I reiterate that neutrality is not generally desirable - setting aside the question whether it is principally possible or not-by bringing forth two points. First, neutrality is sometimes understood in the sense of impartiality; the question of taking sides is primarily a political one. Here, professional ethics should provide orientation for interpreters. If an asylum claimant is treated unfairly, it can be unethical not to take sides. Second, if neutrality means being someone else's (passive) mouthpiece-usually in the sense of verbatim translation-such action can be unprofessional and unethical. Professionalism and professional ethics may require the right intervention at the right time: Sometimes it would simply be unprofessional or unethical for an interpreter not to intervene. ${ }^{9}$

In sum, the importance of 'well qualified, experienced and professionally ethical interpreters provided with appropriate working conditions' (Gill

\footnotetext{
${ }^{9}$ Rycroft (2005), for example, discusses the frustrations an interpreter may face due to the limitations placed on her behavior. If she knows that a misunderstanding may be occurring but is officially prevented from clarifying this because of the rules of conduct she is required to observe, this in my view, is not the right understanding of professional and ethical action.
} 
et al. 2016) cannot be stressed enough. A professional approach to dealing with power, which is related to professional ethics, is necessary in order to prevent situations such as in the examples discussed above. While the issue of professionalism is also pressing in other domains of community interpreting such as communication between physicians and patients, the asylum procedure puts claimants in a particularly vulnerable situation. As basic human rights are at play, it is essential that interpreters can deal with their power in a competent and responsible way. Although it was not possible to systematically collect data on the education or qualifications of the interpreters who interpreted in the observed hearings, the analysis clearly reveals elements of unprofessional behaviour. The findings discussed in this chapter suggest that it is highly problematic to employ interpreters without professional training in asylum hearings.

It is likely that such behaviour is connected to the lack of professional training and might be preventable otherwise. In Austria, the introduction of a voluntary qualification measure for interpreting in the asylum procedure (QUADA) provided by adult education centres in cooperation with UNHCR, introduced in 2015, is a first important step in the right direction. ${ }^{10}$ The curriculum includes, among others, classes on the basics of interpreting as well as its techniques and ethical principles. As the importance of professionalism in interpreting, which includes knowledge of the techniques and ethics of interpreting, cannot be underestimated, especially in the delicate context of asylum applications, I would argue that such training should be compulsory and paid for by the state who is legally responsible for providing a fair hearing. Asylum claimants have a right to a professional interpretation.

The often observed fact that power plays such a crucial role in the interpreted asylum hearing calls for more attention by scholars and practitioners, especially with regard to professionalism and professional ethics.

\section{References}

Angelelli, C. V. (2004). Revisiting the Interpreter's Role: A Study of Conference, Court, and Medical Interpreters in Canada, Mexico, and the United States. Amsterdam and Philadelhpia: John Benjamins.

Angelelli, C. V. (2014). The Sociological Turn in Translation and Interpreting Studies. Amsterdam and Philadelhpia: John Benjamins.

\footnotetext{
${ }^{10}$ The whole course (12 modules) costs $€ 1650$, with the possibility to apply for funding. German skills at B2 level of the EU reference framework are a precondition for participation. Available at: http:// www.vhs.or.at/594 [Accessed 1 July 2017].
} 
Angermeyer, P. S. (2013). Multilingual Speakers and Language Choice in the Legal Sphere. Applied Linguistics Review, 4, 105-126.

Barsky, R. F. (1996). The Interpreter as Intercultural Agent in Convention Refugee Hearings. The Translator, 2(1), 45-63. https://doi.org/10.1080/13556509.1996. 10798963.

Berk-Seligson, S. (2002). The Bilingual Courtroom: Court Interpreters in the Judicial Process. Chicago and London: University of Chicago Press.

Colin, J., \& Morris, R. (1996). Interpreters and the Legal Process (1st ed.). Winchester: Waterside Press.

Dahlvik, J. (2009a). Annäherung an die potentielle Gestaltungsmacht einer Dolmetscherin: eine soziologische Analyse von Interaktionen im Rahmen von gedolmetschten Einvernahmen und Verhandlungen am österreichischen Bundesasylamt und Asylgerichtshof. Master thesis.

Dahlvik, J. (2009b). Interaktion beim Dolmetschen im Asylverfahren: eine Analyse nach dem Modell von Becker-Beck. Master thesis.

Dahlvik, J. (2016). Asylanträge verwalten und entscheiden: der soziologische Blick auf Verborgenes: Eine Forschungsnotiz. Österreichische Zeitschrift für Soziologie, 41, 191-205.

Dahlvik, J. (2018). Inside Asylum Bureaucracy: Organizing Refugee Status Determination in Austria. Springer. https://doi.org/10.1007/978-3-319-63306-0.

Donk, U. (2016[1994]). Der Dolmetscher als Hilfspolizist - Zwischenergebnis einer Feldstudie. Zeitschrift Für Rechtssoziologie, 15(1), 37-57. https://doi. org/10.1515/zfrs-1994-0104.

Froschauer, U., \& Lueger, M. (2009). Interpretative Sozialforschung: der Prozess. Vienna: Facultas WUV.

Gibb, R., \& Good, A. (2014). Interpretation, Translation and Intercultural Communication in Refugee Status Determination Procedures in the UK and France. Language and Intercultural Communication, 14, 385-399.

Gibbels, E., \& Schmitz, J. (2015). Investigating Interventionist Interpreting via Mikhail Bakhtin. Acta Universitatis Carolinae Philologica, 3, 61-72.

Gile, D. (2009). Basic Concepts and Models for Interpreter and Translator Training. Amsterdam and Philadelhpia: John Benjamins.

Gill, N., Rotter, R., Burridge, A., et al. (2016). Linguistic Incomprehension in British Asylum Appeal Hearings. Anthropology Today, 32, 18-21.

Good, A. (2007). Anthropology and Expertise in the Asylum Courts. Abingdon: Routledge-Cavendish.

Good, A. (2011). Tales of Suffering: Asylum Narratives in the Refugee Status Determination Process. West Coast Line, 68, 80-89.

Grbić, N. (2010). "Boundary Work" as a Concept for Studying Professionalization Processes in the Interpreting Field. Translation and Interpreting Studies, 5, 109-123.

Hsieh, E. (2010). Provider-Interpreter Collaboration in Bilingual Health Care: Competitions of Control Over Interpreter-Mediated Interactions. Patient Education and Counseling, 78, 154-159. 
Inghilleri, M. (2003). Habitus, Field and Discourse: Interpreting as a Socially Situated Activity. Target, 15, 243-268.

Inghilleri, M. (2007). National Sovereignty Versus Universal Rights: Interpreting Justice in a Global Context. Social Semiotics, 17, 195-212.

Kadrić, M. (2009). Dolmetschen Bei Gericht: Erwartungen-AnforderungenKompetenzen (3rd ed.). Wien: Facultas.

Lee, J. A. (2014). Pressing Need for the Reform of Interpreting Service in Asylum Settings: A Case Study of Asylum Appeal Hearings in South Korea. Journal of Refugee Studies, 27, 62-81.

Llewellyn-Jones, P., \& Lee, R. G. (2014). Redefining the Role of the Community Interpreter: The Concept of Role-Space. Lincoln: SLI Press.

Maryns, K. (2013). Disclosure and (Re)Performance of Gender-Based Evidence in an Interpreter-Mediated Asylum Interview. Journal of Sociolinguistics, $17,661-686$.

Maryns, K. (2017). The Use of English as Ad Hoc Institutional Standard in the Belgian Asylum Interview. Applied Linguistics, 38(5), 737-758.

Maurer-Kober, B. (2006). Die Rolle von DolmetscherInnen aus juristischer Perspektive. In Österreichisches Bundesministerium für Inneres et al. (Eds.), Handbuch Dolmetschen im Asylverfahren (pp. 28-30). Vienna.

Morris, R. (1995). The Moral Dilemmas of Court Interpreting. The Translator, 1(1), 25-46. https://doi.org/10.1080/13556509.1995.10798948.

Munday, J. (2016). Introducing Translation Studies: Theories and Applications. Oxon and New York: Routledge.

Pöchhacker, F. (2016). Introducing Interpreting Studies. Oxon and New York: Routledge. Pöchhacker, F., \& Kolb, W. (2009). Interpreting for the Record: A Case Study of Asylum Review Hearings. In S. Hale, U. Ozolins, \& L. Stern (Eds.), The Critical Link 5: Quality in Interpreting - a Shared Responsibility (pp. 119-134). Amsterdam and Philadelphia: John Benjamins.

Pöllabauer, S. (2005). "I don't understand your English, Miss": Dolmetschen bei Asylanhörungen. Tübingen: Gunter Narr Verlag.

Pöllabauer, S. (2007). Interpreting in Asylum Hearings. Issues of Saving Face. In C. Wadensjö, B. E. Dimitrova, \& A.-L. Nilsson (Eds.), The Critical Link 4: Professionalisation of Interpreting in the Community: Selected Papers from the 4th International Conference on Interpreting in Legal, Health and Social Service Settings, Stockholm, Sweden, 20-23 May 2004 (pp. 39-52). Amsterdam and Philadelphia: John Benjamins.

Richardson, L. (2000). Writing: A Method of Inquiry. In N. K. Denzin \& Y. S. Lincoln (Eds.), Handbook of Qualitative Research (pp. 923-948). Thousand Oaks, California: Sage.

Rienzner, M. (2011). Interkulturelle Kommunikation im Asylverfahren. Frankfurt am Main, Vienna: Lang.

Rudvin, M. (2007). Professionalism and Ethics in Community Interpreting: The Impact of Individualist Versus Collective Group Identity. Interpreting, 9(1), 47-69. https://doi.org/10.1075/intp.9.1.04rud. 
Rycroft R. (2005). Communicative Barriers in the Asylum Account. In P. Shah (Ed.), The Challenge of Asylum to Legal Systems (pp. 223-244). London: Routledge-Cavendish.

Scheffer, T. (2001). Asylgewährung: eine ethnographische Analyse des deutschen Asylverfahrens. Lucius \& Lucius DE.

Smith, D. E. (2006). Institutional Ethnography as Practice. Rowman \& Littlefield Publishers.

Strauss, A. L., \& Corbin, J. (1990). Basics of Qualitative Research: Grounded Theory Procedures and Techniques. London: Sage.

Tipton, R. (2008). Reflexivity and the Social Construction of Identity in Interpreter-Mediated Asylum Interviews. The Translator, 14, 1-19.

Turner, G., \& Brown, R. (2001). Interaction and the Role of the Interpreter in Court. In F. J. Harrington \& G. H. Turner (Eds.), Interpreting Interpreting: Studies and Reflections on Sign Language Interpreting (pp. 152-167). Coleford, UK: Douglas McLean.

UNHCR Österreich. (2015). Trainingshandbuch für DolmetscherInnen im Asylverfahren, UNCHR. Global Trends. Forced Displacement in 2015. Available at: http://www.unhcr.org/576408cd7.

Wadensjö, C. (1999). Interpreting as Interaction. London: Pearson Education ESL.

Wadensjö, C. (2007). Foreword: Interpreting professions, professionalisation and professionalism. In C. Wadensjö, B. E. Dimitrova, \& A.-L. Nilsson (Eds.), The Critical Link 4: Professionalisation of Interpreting in the Community: Selected Papers from the 4th International Conference on Interpreting in Legal, Health and Social Service Settings, Stockholm, Sweden, 20-23 May 2004 (pp. 1-8). Amsterdam and Philadelphia: John Benjamins.

Wolf, M., \& Fukari, A. (2007). Constructing a Sociology of Translation. Amsterdam and Philadelphia: John Benjamins.

Open Access This chapter is distributed under the terms of the Creative Commons Attribution 4.0 International License (http://creativecommons.org/licenses/ by/4.0/), which permits use, duplication, adaptation, distribution and reproduction in any medium or format, as long as you give appropriate credit to the original author(s) and the source, a link is provided to the Creative Commons license and any changes made are indicated.

The images or other third party material in this chapter are included in the work's Creative Commons license, unless indicated otherwise in the credit line; if such material is not included in the work's Creative Commons license and the respective action is not permitted by statutory regulation, users will need to obtain permission from the license holder to duplicate, adapt or reproduce the material.

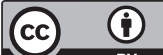

